\title{
Effect of exogenous protease enzymes on the fermentation and nutritive value of corn silage ${ }^{1}$
}

\author{
K. M. Young, J. M. Lim, M. C. Der Bedrosian, and L. Kung Jr. ${ }^{2}$ \\ Department of Animal and Food Sciences, University of Delaware, Newark 19717-1303
}

\begin{abstract}
The objective of this study was to evaluate the effects of adding experimental formulations of exogenous protease enzymes on the fermentation and nutritive value of whole-plant corn ensiled in laboratory silos. Chopped and processed whole-plant corn $(36.8 \% \mathrm{DM})$ was ensiled without enzymes or treated with 1 of 2 experimental proteases (E85 or E86; AB Vista, Wiltshire, UK) at 20 or $2,000 \mathrm{mg} / \mathrm{kg}$ (wet-weight basis). Forages were packed in vacuumed and heat-sealed bags and ensiled for 45 and $150 \mathrm{~d}$ at $23 \pm 1^{\circ} \mathrm{C}$. When compared with untreated silage, addition of proteases and length of ensiling time had no effect on silage $\mathrm{pH}$ or concentration of crude protein. The results were similar for the concentrations of acid detergent fiber, neutral detergent fiber, and starch, although protease $\times$ time interactions were observed for these components, which were biologically minor. When compared with untreated silages, only treatment with the $2,000-\mathrm{mg} / \mathrm{kg}$ application amount of E85 resulted in lower neutral detergent fiber after $45 \mathrm{~d}$ of ensiling. Proteases did not affect NDF digestibility after $150 \mathrm{~d}$ of ensiling when compared with untreated silage. Similarly, treatment with enzymes did not affect the concentrations of lactic and acetic acids or ethanol when compared with untreated silage. Concentrations of $\mathrm{NH}_{3}-\mathrm{N}$ and soluble protein (\% of crude protein) increased with storage time compared with concentrations at harvest and were greater for the $2,000-\mathrm{mg} / \mathrm{kg}$ doses of proteases when compared with untreated silage at both 45 and $150 \mathrm{~d}$. In vitro ruminal digestibility of starch after $7 \mathrm{~h}$ of incubation was $66.3 \%$ for freshly chopped corn plants. After $45 \mathrm{~d}$ of ensiling, starch digestion was greater for E86 applied at the 2,000-mg/ $\mathrm{kg}$ dose $(80.6 \%)$ than in all other treatments, with the exception that it was similar to the $2,000-\mathrm{mg} / \mathrm{kg}$ dose of E85. After $150 \mathrm{~d}$ of ensiling, the $20-\mathrm{mg} / \mathrm{kg}$ dose of E85 (81.9\%), the $2,000-\mathrm{mg} / \mathrm{kg}$ dose of E85 (82.9\%), and the

\footnotetext{
Received April 16, 2012.

Accepted July 2, 2012.

${ }^{1}$ This research was conducted by K. M. Young as partial fulfillment ${ }^{2}$ Corresponding author: lksilage@udel.edu
} for a degree with distinction as an undergraduate student in the University of Delaware's Science and Engineering Scholar's Program.
\end{abstract}

2,000-mg/kg dose of E86 (88.6\%) had greater starch digestibility than untreated silage $(74.0 \%)$. To the best of our knowledge, this is the first study to show that addition of exogenous proteases added to corn forage at the time of harvest can increase in vitro ruminal starch digestibility during silage fermentation. Data suggests that adding exogenous sources of protease enzymes at ensiling may be a method to obtain a high degree of ruminal starch digestibility in corn silage that would normally require longer periods of time to obtain from prolonged storage.

Key words: protease, silage, starch, digestion

\section{INTRODUCTION}

Dairy producers must often feed forages that have only been ensiled for a few days or weeks. This situation possesses several potential issues. First, fresh forages contain high levels of water-soluble carbohydrates, which, if consumed in large amounts without ruminal adaptation, can lead to subacute acidosis. Second, recent studies have shown that corn silage and high-moisture corn fermented for several months have higher values of in vitro ruminal starch digestion than the same feeds before ensiling (Benton et al., 2005; Newbold et al., 2006). Thus, the nutritive value of some crops is not maximized until they are ensiled for several months. Hoffman et al. (2011) suggested that proteolytic activity was responsible for the degradation of hydrophobic zein proteins in high-moisture corn over extended periods of ensiling, which might explain why potential ruminal starch digestion increases with time of storage. Proteolysis during the natural ensiling process occurs due to microbial and plant proteases, but the majority of activity in good fermentations appears to be from the latter (Heron et al., 1986). Heron et al. (1989) reported plant protease activity below $\mathrm{pH} 4$ and chemical hydrolysis below $\mathrm{pH} 3$ in ryegrass extracts. Some proteolysis occurring during prolonged storage may also come from microbial sources, as some lactic acid bacteria (LAB) are metabolically active in silage for a long time (Kleinschmit and Kung, 2006). Regardless of where residual proteolytic activity comes from during prolonged ensiling, the addition of exogenous 
protease enzymes to corn plants at harvest could improve starch digestion. Such proteases would need to be active right away, survive the ensiling process (not be inactivated or degraded) and express good activity at the temperatures (e.g., 25 to $40^{\circ} \mathrm{C}$ ) and $\mathrm{pH}$ (e.g., approximately 3.8 to 4.0 for corn silage and 4.5 to 4.8 for high-moisture corn) of the selected type of silage.

The objective of this study was to evaluate the effects of adding experimental formulations of exogenous protease enzymes on the fermentation and nutritive value of whole-plant corn ensiled in laboratory silos. In particular, we were interested in the ability of the proteases to increase potential ruminal starch digestibility after short periods of ensiling. Our hypothesis was that adding proteases at the time of ensiling would have the ability to accelerate the increase in starch digestion normally achieved by prolonged times of ensiling.

\section{MATERIALS AND METHODS}

Whole-plant corn (Mycogen Seeds TMF2W726; Dow AgroSciences, Indianapolis, IN) was harvested at 36.8\% $\mathrm{DM}$ and chopped (19-mm theoretical length) with a pull-type harvester equipped with a mechanical processor (New Holland FP230; New Holland Agriculture, New Holland, PA). Forages from 4 random sections of a field were chopped. For each section, 5 subsections were prepared and treated separately with (1) water, untreated forage; (2) $20 \mathrm{mg} / \mathrm{kg}$ of enzyme formulation E85 (E85-L; AB Vista, Wiltshire, UK); (3) 2,000 mg/ $\mathrm{kg}$ of E85 (E85-H); (4) $20 \mathrm{mg} / \mathrm{kg}$ of enzyme formulation E86 (E86-L; AB Vista); or (5) $2,000 \mathrm{mg} / \mathrm{kg}$ of E86 (E85-H). Thus, there were a total of 20 piles of chopped corn plants. Formulation E85 was derived from Aspergillus niger and E86 was a mixture of the E85 plus crude extracts from Trichoderma spp. The $20-\mathrm{mg} / \mathrm{kg}$ application was applied per the manufacturer's recommendation and the $2,000-\mathrm{mg} / \mathrm{kg}$ dose was added as a higher dose. Enzymes were assayed for activity at $\mathrm{pH}$ 3 , 4, and 5 at $50^{\circ} \mathrm{C}$ using hemoglobin as the substrate (Sigma-Aldrich Co. LLC, 1996). They contained 1,865 and $156 \mathrm{U}$ of activity/mg of solids for E85 and E86, respectively, where $1 \mathrm{U}$ of activity produced a change in absorbency at $280 \mathrm{~nm}\left(\Delta \mathrm{A}_{280 \mathrm{~nm}}\right)$ of 0.001 per minute at the $\mathrm{pH}$ and temperature used, measured as TCAsoluble products using hemoglobin as a substrate. Both enzymes showed higher activity at $\mathrm{pH} 3$ than at $\mathrm{pH} 4$ or 5 (Figure 1). Enzymes were dissolved into phosphate buffer ( $\mathrm{pH} 5.5$ ) and applied by a spray bottle to the piles of forage while mixing. A different spray bottle was used for each treatment to avoid cross-contamination between treatments. Forty-two milliliters of phosphate buffer mixed with enzyme was sprayed onto piles of 2 $\mathrm{kg}$ of forage. A similar amount of buffer was sprayed onto piles not receiving enzyme so that equal amounts of moisture were added to all forages. Each pile for each treatment was mixed well and the forage was packed into $25.4 \times 35.6$-cm embossed vacuum pouches (3.5 mil, nylon-polyethylene; Doug Care Equipment Inc., Springville, CA) containing approximately $500 \mathrm{~g}$ of forage per bag. A sample was taken from each of the control piles for fresh forage analysis on d 0. Air was removed with a Best Vac vacuum sealer (Doug Care Equipment Inc.), heat-sealed, and stored at room temperature $\left(23 \pm 1^{\circ} \mathrm{C}\right)$ for 45 and $150 \mathrm{~d}$ of ensiling.

For each replicate of fresh forage and ensilage, $25 \mathrm{~g}$ of representative sample was blended in $225 \mathrm{~mL}$ of sterile one-fourth strength Ringer's solution (Oxoid BR52; Oxoid, Unipath Ltd., Basingstoke, UK) for $1 \mathrm{~min}$. The $\mathrm{pH}$ of each sample was determined, and a portion of the water extract was filtered through Whatman 54 filter paper (Whatman Inc., Clifton, NJ). Water extracts $(4 \mathrm{~mL})$ were acidified with $25 \mu \mathrm{L}$ of $50 \% \mathrm{H}_{2} \mathrm{SO}_{4}$, and
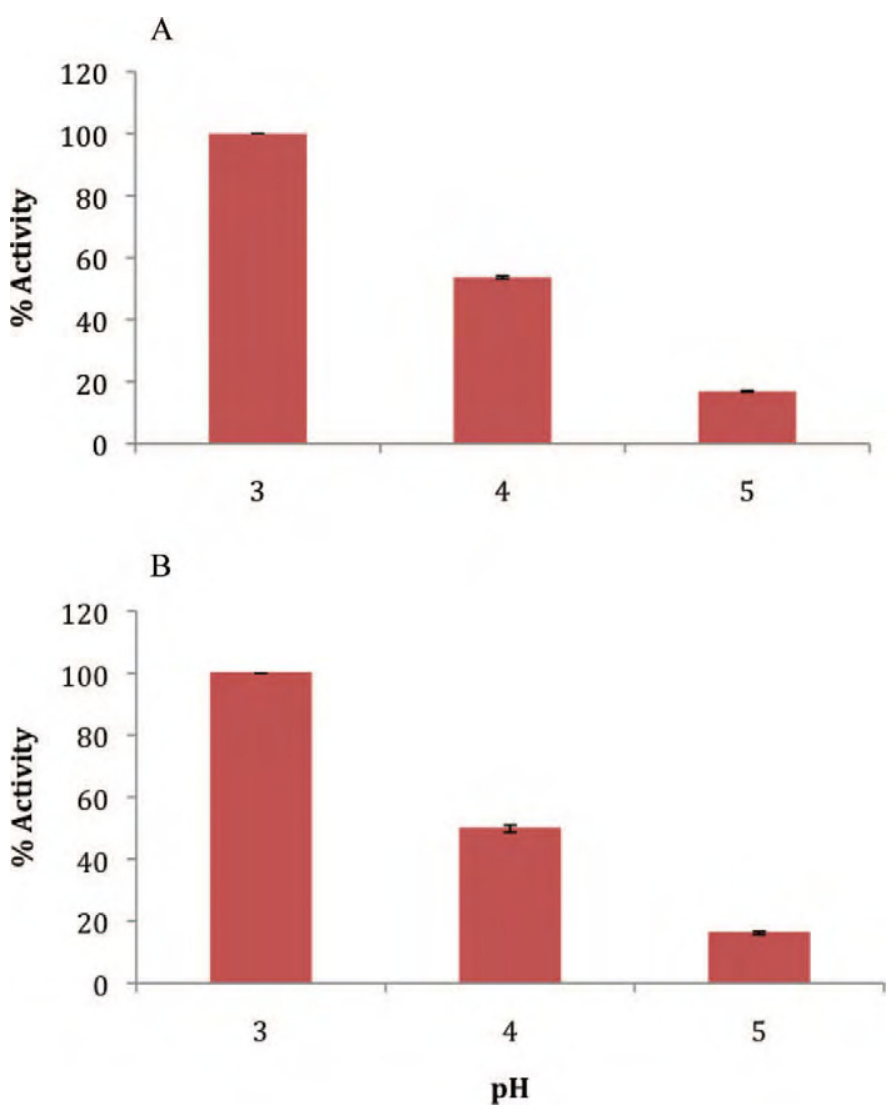

Figure 1. Proteolytic activity as a percentage of activity at $\mathrm{pH} 3$ at $50^{\circ} \mathrm{C}(100 \%)$ for E85 (A) and E86 (B) enzymes (AB Vista, Wiltshire, UK) used in the study. The enzymes contained 1,865 and $156 \mathrm{U}$ of activity/mg of solids for E85 and E86, respectively. One unit produced a change in absorbency at $280 \mathrm{~nm}\left(\Delta \mathrm{A}_{280 \mathrm{~nm}}\right)$ of 0.001 per minute at the $\mathrm{pH}$ and temperature used, measured as TCA-soluble products using hemoglobin as a substrate. Error bars represent the standard deviation of the replicated assay. Color version available in the online PDF. 
frozen before analysis of fermentation end products. Water extracts from d 45 and 150 were analyzed for lactic acid, ethanol, and VFA by HPLC following the method of Muck and Dickerson (1988). The DM content of each sample was determined by drying samples in a force-draft oven set at $60^{\circ} \mathrm{C}$ for $48 \mathrm{~h}$. Ammonia-N was determined on the water extract by the phenolhypochlorite method of Weatherburn (1967). A portion of the water extracts was used for enumeration of LAB by pour-plating on de Man, Rogosa, and Sharpe (MRS) agar (Oxoid CM361; Oxoid, Unipath Ltd.). Yeasts and molds were determined by plating on yeast and mold Petrifilm (3M Microbiology Products, St. Paul, MN). Plates and films were incubated aerobically at $32^{\circ} \mathrm{C}$ for 48 to $72 \mathrm{~h}$ and plates or films containing between 30 and $300 \mathrm{cfu}$ were used for counting.

Dried forage and silage samples were analyzed for nutrient content and estimates of in vitro digestibility by Cumberland Valley Analytical Laboratories (Maugansville, MD). Analyses included the determination of total $\mathrm{N}$ concentration by combustion of the sample (Leco CNS 2000 Analyzer; Leco Corp., St. Joseph, MI) and CP was calculated by multiplying the resulting total $\mathrm{N}$ by 6.25 . Soluble protein (SP, \% of $\mathrm{CP})$ concentration was determined by the method of Krishnamoorthy et al. (1982). The starch content of samples was determined and corrected for free glucose according to the procedures described by Hall (2009). Neutral detergent fiber was quantified through the procedures of Van Soest et al. (1991), using amylase and sodium sulfite. The ADF concentration of feeds was as outlined by AOAC International (2000) with the modification of using Whatman 934-AH glass microfiber filters with 1.5-um particle retention used in place of fritted glass crucibles. Analysis of NDF and $\mathrm{ADF}$ was not sequential and their concentrations are reported on a DM (not ash-free) basis. The in vitro digestibility of NDF (NDF-D) was determined after $30 \mathrm{~h}$ of incubation on dried samples ground through a Wiley mill (Thomas Scientific, Swedesboro, NJ) to pass though a 1 -mm screen and a 7 -h in vitro starch digestibility was performed (Tilley and Terry, 1963) on dried samples ground to pass through a $3-\mathrm{mm}$ screen. All samples for each determination were run in duplicate and replicated on 3 individual days. Ruminal fluid was pooled from 3 lactating cows with rumen fistula that were fed a standard diet comprising $25 \%$ corn silage, $25 \%$ alfalfa haylage, and $50 \%$ concentrate (DM basis).

All chemical analyses are presented on a DM basis (unless stated otherwise) and microbial data are presented on a wet-forage basis and converted to logarithm base $10\left(\log _{10}\right)$. The data were analyzed as a $2 \times 5$ factorial arrangement of treatments (2 times of storage and 5 treatments) using the Fit Model procedure of
JMP software (version 8.02; SAS Institute, 2011). Main effects were treatment with enzyme, time of storage, their interaction, and residual error included in the model. Means were separated by the Tukey test $(P \leq$ 0.05; Snedecor and Cochran, 1980).

\section{RESULTS}

Table 1 shows the DM, pH, nutrient content, microbial populations, in vitro digestibility of starch (starchD), and NDF-D for fresh forage before treatment and ensiling. Fresh forage contained $36.80 \%$ DM, $9.74 \%$ CP, $24.14 \% \mathrm{ADF}$, and $28.23 \%$ starch. The in vitro starchD was $66.34 \%$ in fresh forage. Freshly chopped forage contained 7.40 and $6.39 \mathrm{log} \mathrm{cfu} / \mathrm{g}$ of yeasts and molds, respectively. The numbers of LAB was $8.89 \mathrm{log} \mathrm{cfu} / \mathrm{g}$ in fresh forage.

Table 2 shows the DM, chemical composition, and NDF-D of silages after 45 and $150 \mathrm{~d}$ of ensiling. Although the DM content of silages was affected by treatment with protease $(P<0.03)$ and time of storage $(P<0.01)$, within a day, the DM content of silages treated with proteases was not different from untreated silage. An interaction $(P<0.01)$ was observed between treatment with protease and time of storage for SP specifically because its concentration increased for all treatments with time of storage, with the exception of E86-H. Additions of high levels of both enzymes resulted in higher concentrations of soluble $\mathrm{N}$ when compared with untreated silage at both times of ensiling. Averaged over the main effects, the concentration of $\mathrm{NH}_{3}-\mathrm{N}$ increased with time of storage (0.14 to $0.16 \%)$. Treatment with the $2,000-\mathrm{mg} / \mathrm{kg}$ levels of proteases resulted in higher concentrations of $\mathrm{NH}_{3}-\mathrm{N}(P<0.01)$ when compared with untreated silage and silages treated

Table 1. The DM (\%), pH, nutrient content (DM basis unless stated otherwise), and microbial populations (fresh-weight basis) of fresh forage

\begin{tabular}{lc}
\hline Item & Mean $^{1} \pm \mathrm{SD}$ \\
\hline $\mathrm{DM}, \%$ & $36.80 \pm 1.06$ \\
$\mathrm{pH}$ & $5.75 \pm 0.09$ \\
$\mathrm{CP}, \%$ & $9.74 \pm 0.39$ \\
Soluble protein, \% of CP & $29.90 \pm 2.27$ \\
$\mathrm{NH}_{3}-\mathrm{N}, \%$ & $0.06 \pm<0.01$ \\
$\mathrm{ADF}, \%$ & $24.14 \pm 3.21$ \\
$\mathrm{NDF}, \%$ & $41.94 \pm 2.68$ \\
$\mathrm{NDF}-\mathrm{D},{ }^{2} \%$ of NDF & $63.80 \pm 1.28$ \\
Starch, \% & $28.23 \pm 3.10$ \\
Starch-D, ${ }^{3} \%$ of starch & $66.34 \pm 4.00$ \\
Yeasts, log cfu/g & $7.40 \pm 0.14$ \\
Molds, log cfu/g & $6.39 \pm 0.10$ \\
Lactic acid bacteria, log cfu/g & $8.89 \pm 0.29$ \\
\hline${ }^{1} \mathrm{n}=4$. & \\
${ }^{2}$ In vitro ruminal NDF digestion, 24-h incubation. \\
${ }^{3}$ In vitro ruminal starch digestion, 7-h incubation.
\end{tabular}


with the lower concentrations of protease. Interactions were observed between treatment with proteases and time of storage for the concentrations of $\operatorname{ADF}(P<$ $0.01)$, NDF $(P<0.01)$, and starch $(P<0.02)$. The concentrations of ADF and NDF slightly decreased with time of storage when treated with E86 but this did not occur in untreated silage or silage treated with E85. In contrast, the concentration of starch was unaffected by treatment with protease or time of storage. The digestibility of NDF-D decreased by 1 percentage unit with increasing time of storage $(P<0.02)$. When averaged across sampling times, treatment with E85-H resulted in lower NDF-D (58.9\%) than untreated silage (61.4\%).

The in vitro digestibility of starch after 45 and $150 \mathrm{~d}$ of ensiling is shown in Figure 2. A protease $\times$ time of storage interaction $(P<0.01)$ existed because starch-D remained relatively unchanged for untreated corn silage between 45 and $150 \mathrm{~d}$, whereas it increased for some protease treatments. Specifically at d 45, treatment with E86-H resulted in a marked increase in starch-D $(80.6 \%)$ compared with untreated silage (73.5\%). After $150 \mathrm{~d}$ of ensiling, starch-D was higher in E85-L and E85-H when compared with untreated silage. Treatment with E86-H resulted in starch-D that was higher than all of these 3 treatments. No effect of E86-L on starch-D was observed when compared with untreated silage after $150 \mathrm{~d}$ of ensiling.

The $\mathrm{pH}$, fermentation end products and microbial populations in silages are shown in Table 3. All silages fermented well, as the $\mathrm{pH}$ ranged from 3.68 to 3.83 after $45 \mathrm{~d}$, and ranged from 3.69 to 3.77 after $150 \mathrm{~d}$ of ensiling. The $\mathrm{pH}$ of silages was not affected by treatment with proteases or time of storage. Over time, the concentrations of lactic $(5.78$ to $6.58 \%, P<0.02)$ and acetic acid (1.50 to $1.77 \%, P<0.01)$ increased from d 45 to d 150. Similarly the concentration of ethanol tended $(P<0.10)$ to increase $(3.98$ to $4.42 \%)$ between these days when averaged across all treatments. Averaged across time of ensiling, treatment with E85-L and E86-L resulted in numerically greater concentrations of lactic acid, acetic acid, and ethanol compared with untreated silage. Treatment with E85-H (7.19\% lactic acid and $4.65 \%$ ethanol) and $\mathrm{E} 86-\mathrm{H}$ (7.04\% lactic acid and $4.70 \%$ ethanol) resulted in statistically higher concentrations of lactic acid $(P<0.01)$ and ethanol $(P$ $<0.03)$ when compared with untreated silage $(5.06 \%$ lactic acid and $3.51 \%$ ethanol). Additionally, treatment with E85-L and E86-H had higher $(P<0.01)$ concentrations of acetic acid compared with untreated silage. Treatment with proteases had no effects on the numbers of yeasts and molds or LAB in corn silage when averaged over the 2 times of ensiling but numbers of yeasts declined with time of storage $(P<0.01)$. Treatment with proteases did not affect the number of

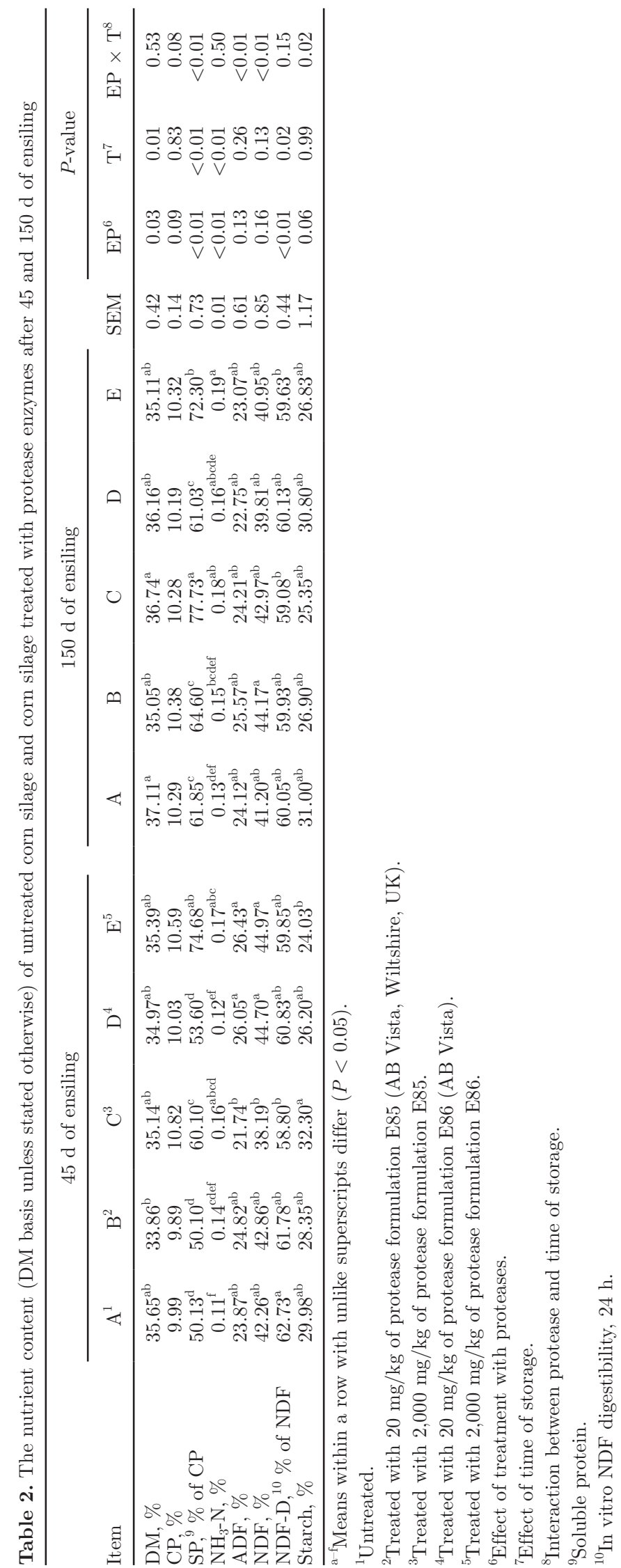




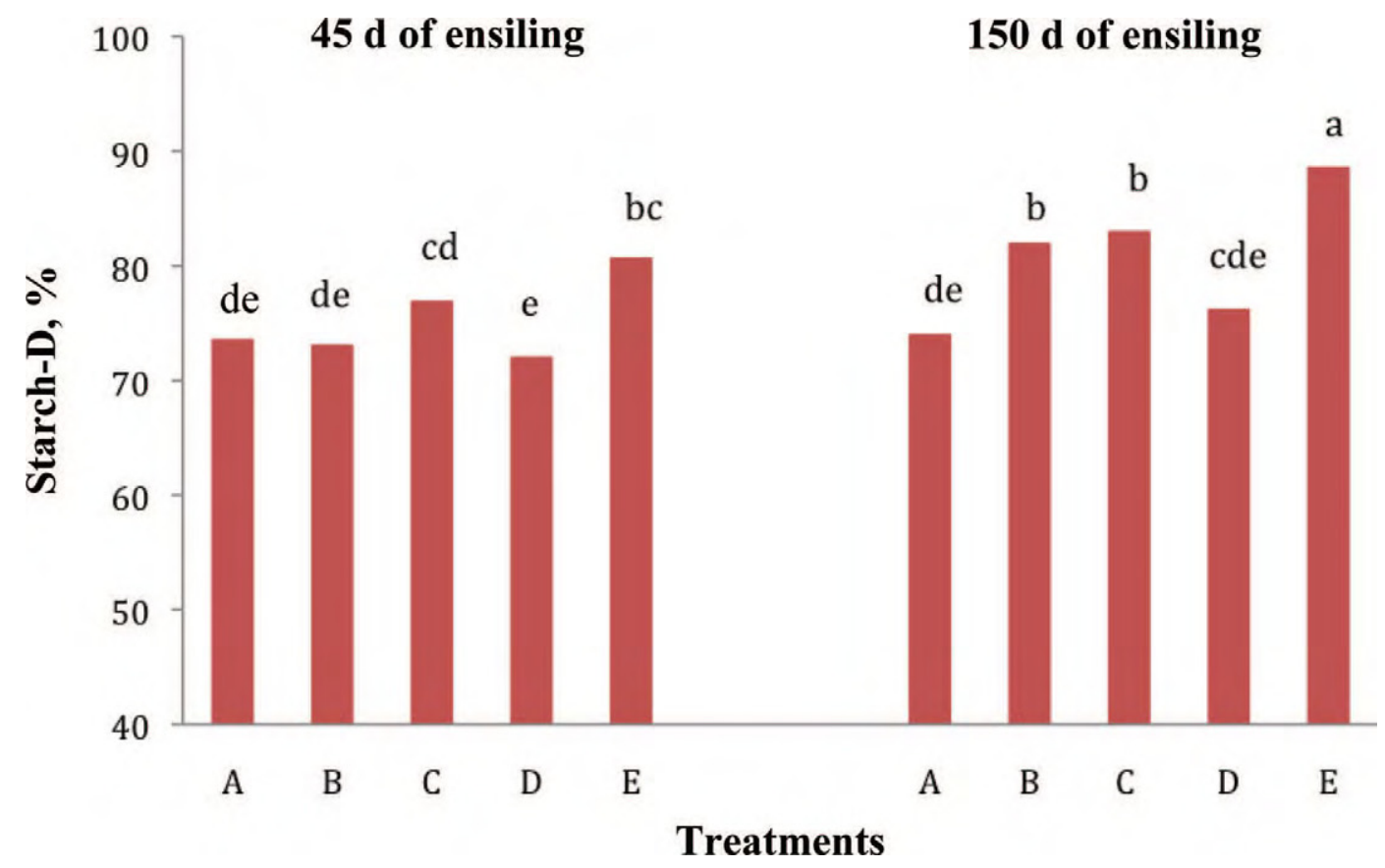

Figure 2. In vitro starch digestion (starch-D; $7 \mathrm{~h}, \%$ of starch) of corn silages that had been treated with protease enzymes at harvest after 45 and $150 \mathrm{~d}$ of ensiling. Bars with unlike lowercase letters $(\mathrm{a}-\mathrm{e})$ differ $(P<0.01)$. Protease effect: $P<0.01$; time of storage effect: $P<$ 0.01 ; protease $\times$ storage interaction: $P<0.01, \mathrm{SEM}=0.65 . \mathrm{A}=$ untreated silage; $\mathrm{B}=$ silage treated with $20 \mathrm{mg} / \mathrm{kg}$ of enzyme $85(\mathrm{AB} \mathrm{Vista}$, Wiltshire, UK); C = silage treated with $2,000 \mathrm{mg} / \mathrm{kg}$ of enzyme $85 ; \mathrm{D}=$ silage treated with $20 \mathrm{mg} / \mathrm{kg}$ of enzyme 86 (AB Vista, Wiltshire, UK); $\mathrm{E}=$ silage treated with $2,000 \mathrm{mg} / \mathrm{kg}$ of enzyme 86 . Color version available in the online PDF.

molds or LAB but numbers of molds increased $(P<$ 0.01 ) with time of storage, whereas numbers of LAB decreased with time of storage.

\section{DISCUSSION}

The corn forage used in this study was of similar chemical and microbial composition compared with forage used in previous studies, with the exception that the numbers of LAB were slightly higher than normal (Reich and Kung, 2010; Schmidt and Kung, 2010). The concentrations of $\mathrm{CP}, \mathrm{ADF}, \mathrm{NDF}$, and starch did not change between 45 and $150 \mathrm{~d}$ of ensiling and agrees with the findings of Der Bedrosian et al. (2012). Although NDF-D was lower in silages at 150 than 45 $\mathrm{d}$, it was only 1 percentage unit lower. As expected, the concentrations of $\mathrm{SP}$ and NH3-N increased with time of ensiling (Der Bedrosian et al., 2012), indicating that proteolytic mechanisms were active. These findings were accompanied by an increase in starch-D with time of ensiling, as it was $66.34,75.22$, and $80.71 \%$ for fresh, 45-d, and 150-d samples, respectively. Overall, the data generally verify the fact that concentrations of starch and fiber and digestibility of fiber are relatively unaffected, but that starch-D increases with time of ensiling, probably due to proteolysis.
Prolamin proteins form a matrix surrounding starch granules in corn (Simpson, 2001). Because of their hydrophobic nature, prolamins present a major barrier hampering the access to corn starch by enzymes. To overcome this barrier, acid proteases are commonly used to increase the yield of ethanol in corn fermentation (Wang et al., 2009). Past research has shown that pretreating feeds with proteases improves starch digestion by rumen bacteria (McAllister et al., 1993; DePeters et al., 2007). Eun and Beauchemin (2007) also reported improvements to in vitro starch digestion in corn silage with added papain but Colombatto et al. (2003) reported no effect of protease enzymes from Bacillus licheniformis on starch digestion. In nature, prolamins are degraded during germination by internal cysteine endoproteases and the resulting peptides are degraded by serine carboxypeptidases (Simpson, 2001). The result of this process is a source of AA for the plant embryo. Although we did not know the specific types of protease from the extracts we used in the current study, a wide range of proteases are produced by species of Aspergillus and Trichoderma. Specifically, serine proteases are commonly found in Aspergillus niger (Dal Degan et al., 1992) and Trichoderma spp. (Shakeri and Foster, 2007) and aspartic proteases (with activity at low $\mathrm{pH}$, which would be essential for use in fermented 


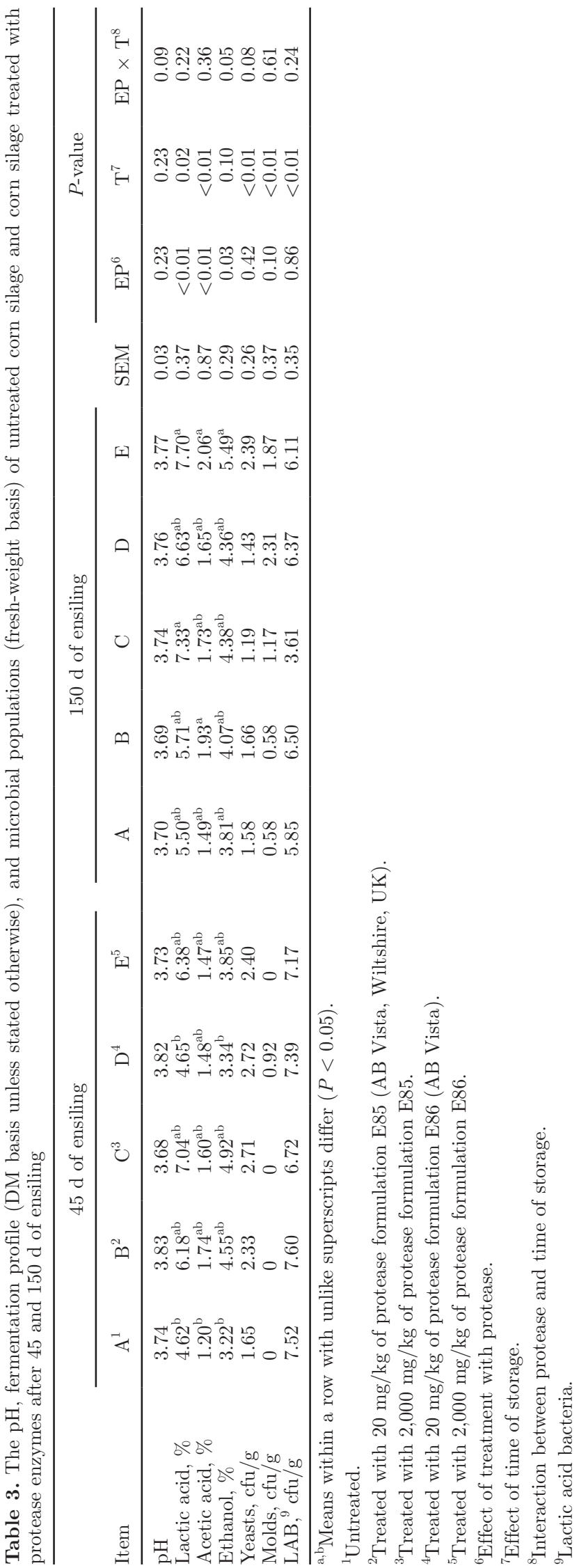

feeds) have also been found in species of $A$. niger (Wang et al., 2008; Siala et al., 2009). Both plant and microbial proteases naturally contribute to proteolysis during ensiling (Rooke and Hatfield, 2003). Hoffman et al. (2011) recently suggested that continued proteolytic activity rather than solubilization of prolamin proteins by acids and ethanol probably explains the improvement in starch-D in silages with increasing time of storage. In our study, concentrations of soluble protein and $\mathrm{NH}_{3}-\mathrm{N}$ markedly increased from low levels in fresh forage to moderate levels in silages stored for $45 \mathrm{~d}$ and further increased after $150 \mathrm{~d}$ of ensiling. The one exception for that increase was for $\mathrm{E} 86-\mathrm{H}$, perhaps because the maximum amount of proteolysis may have been reached for this silage early during ensiling. Addition of the $2,000 \mathrm{mg} / \mathrm{kg}$ of exogenous enzymes resulted in additional proteolysis, as soluble $\mathrm{N}$ was greater for these treatments than in untreated silage after 45 and 150 d. The data on starch-D from our study supported our hypothesis that adding exogenous proteases enzymes to chopped corn plants at harvest has the potential to improve starch availability. The $2000-\mathrm{mg} / \mathrm{kg}$ levels of E-85 and E-86 consistently resulted in higher starchD when compared specifically with untreated silage at both sampling times and starch-D from E86-H was greatest for all treatments after $150 \mathrm{~d}$.

Although not statistically different, treatment with the proteases resulted in numerically lower concentrations of starch but numerically higher concentrations of acids and ethanol compared with untreated silage after $150 \mathrm{~d}$ of ensiling. Increased fermentation and ethanol production have been reported when supplemental proteases were added to starch to make ethanol (Wang et al., 2009; Guo et al., 2011). Additionally, the crude enzyme extracts we used could have contained some carbohydrase activity (as Aspergillus and Trichoderma spp. are known to produce both amylase and protease enzymes), although we did not test for this in the current study. Perhaps treatment with enzymes in our study allowed for easier access to starch during ensiling and (or) released more AA that could have been used by microorganisms in the silage, which, in turn, resulted in a stimulation of fermentation.

Research showing that increased time of storage results in improved potential for ruminal starch digestion in corn silage has resulted in some dairymen altering their silage inventories to ensure that silage has ensiled for at least 4 to 6 mo before being fed. This can cause challenges because it requires added space for silage inventory and diligent management of silo integrity to prevent penetration of oxygen into the silage mass during prolonged storage. In addition, many silages in small silos are exposed to cold temperatures that probably curtail the natural proteolytic process in the silo 
for a period of time. Our data suggests that adding an exogenous protease enzymes at ensiling may be a viable method to improve starch-D in corn silage and other high-starch crops without having to wait for this process to occur naturally. This approach, may be questioned by some because it has been generally accepted that proteolysis is often excessive in silages (Rooke and Hatfield, 2003) and various attempts have been made to reduce (Winters et al., 2008), rather than enhance, proteolysis in silages. However, most work in this area has been targeted at inhibiting proteolysis in legume and grass silages (Wetherall et al., 1995; Winters et al., 2008).

Improved starch-D at the expense of increased proteolysis by the addition of proteases may be acceptable in feeds such as corn silage, high-moisture corn, snaplage, and sorghum silage, but many questions on the use of proteases for this purpose remain unanswered. For example, many proteases have temperature optimums that are quite high $\left(45-50^{\circ} \mathrm{C}\right)$ and this may affect how fast an exogenous protease may work, especially if the crop is harvested in a cold environment. The efficacy of an added protease might also be affected by the degree of kernel processing, which might affect the interaction between an added enzyme and the surface area of starch where it must make contact. Additionally, research is needed to ensure that treatment with exogenous proteases for prolonged periods of time does not result in excessive proteolysis and deamination. If it does, treatment with proteases could be targeted to silages that would be fed out quickly and not be kept for long periods $(>6 \mathrm{mo})$ of time.

\section{CONCLUSIONS}

Ensiling whole plant corn with high levels of 2 experimental formulations of protease enzymes resulted in increases in soluble protein and $\mathrm{NH}_{3}-\mathrm{N}$ that were accompanied by increases in starch-D. To our best knowledge, this is the first study to show that addition of exogenous proteases at the time of ensiling can increase the potential ruminal digestion of starch in corn silage. Some caution should be taken when interpreting the results of this study because it was conducted under controlled laboratory conditions with 1 corn hybrid harvested at a specific maturity and stored under a stable temperature. Further research will also be required to determine optimal doses and the cost benefit ratio of treating corn silage with protease enzymes.

\section{ACKNOWLEDGMENTS}

We thank Nicola Walker of AB Vista Feed Ingredients (Marlborough, UK) for providing the enzymes used in this study. We also thank the staff at the University of Delaware Farm for assistance with growing and harvesting of the corn crop.

\section{REFERENCES}

AOAC International. 2000. Official Methods of Analysis. 17th ed. AOAC International, Gaithersburg, MD.

Benton, J. R., T. Klopfenstein, and G. E. Erickson. 2005. Effects of corn moisture and length of ensiling on dry matter digestibility and rumen degradable protein. Nebraska Beef Cattle Reports: 31-33. Univ. Nebraska, Lincoln.

Colombatto, D., G. Hervás, W. Z. Yang, and K. A. Beauchemin. 2003. Effects of enzyme supplementation of a total mixed ration on microbial fermentation in continuous culture, maintained at high and low pH. J. Anim. Sci. 81:2617-2627.

Dal Degan, F., B. Ribadeau-Dumas, and K. Breddam. 1992. Purification and characterization of two serine carboxypeptidases from $A s$ pergillus niger and their use in C-terminal sequencing of proteins and peptide synthesis. Appl. Environ. Microbiol. 58:2144-2152.

DePeters, E. J., G. Getachew, J. G. Fadel, L. Corona, and R. A. Zinn. 2007. Influence of corn hybrid, protease and methods of processing on in vitro gas production. Anim. Feed Sci. Technol. 135:157-175.

Der Bedrosian, M. C., L. Kung Jr., and K. E. Nestor Jr. 2012. The effects of hybrid, maturity, and length of storage on the nutritive value of corn silage. J. Dairy Sci. 95:5115-5126.

Eun, J.-S., and K. A. Beauchemin. 2007. Enhancing in vitro degradation of alfalfa hay and corn silage using feed enzymes. J. Dairy Sci. 90:2839-2851.

Guo, Z., C. Qiu, L. Zhang, Z. Ding, Z.-X. Wang, and G.-Y. Shi. 2011. Expression of aspartic protease from Neurospora crassa in industrial ethanol-producing yeast and its application in ethanol production. Enzyme Microb. Technol. 48:148-154.

Hall, M. B. 2009. Determination of starch, including maltooligosaccharides, in animal feeds: Comparison of methods and a method recommended for AOAC collaborative study. J. AOAC Int. 92:42-49.

Heron, S. J. E., R. A. Edwards, and P. McDonald. 1986. Changes in the nitrogenous components of gamma-irradiated and inoculated ensiled ryegrass. J. Sci. Food Agric. 37:979-985.

Heron, S. J. E., R. A. Edwards, and P. Phillips. 1989. Effect of pH on the activity of ryegrass Lolium multiflorum proteases. J. Sci. Food Agric. 46:267-277.

Hoffman, P. C., N. M. Esser, R. D. Shaver, W. K. Coblentz, M. P. Scott, A. L. Bodnar, R. J. Schmidt, and R. C. Charley. 2011. Influence of ensiling time and inoculation on alteration of the starchprotein matrix in high-moisture corn. J. Dairy Sci. 94:2465-2474.

Kleinschmit, D. H., and L. Kung Jr. 2006. The effects of Lactobacillus buchneri 40788 and Pediococcus pentosaceus R1094 on the fermentation of corn silage. J. Dairy Sci. 89:3999-4004.

Krishnamoorthy, U., T. V. Muscato, C. J. Sniffen, and P. J. Van Soest. 1982. Nitrogen fractions in selected feedstuffs. J. Dairy Sci. 65:217-225.

McAllister, T. A., R. C. Phillippe, L. M. Rode, and K. J. Cheng. 1993. Effect of the protein matrix on the digestion of cereal grains by ruminal microorganisms. J. Anim. Sci. 71:205-212.

Muck, R. E., and J. T. Dickerson. 1988. Storage temperature effects on proteolysis in alfalfa silage. Trans. ASAE 31:1005-1009.

Newbold, J. R., E. A. Lewis, L. Lavrijssen, H. J. Brand, H. Vedder, and J. Bakker. 2006. Effect of storage time on ruminal starch degradability in corn silage. J. Dairy Sci. 89(Suppl. 1):T94. (Abstr.)

Reich, L. J., and L. Kung Jr. 2010. Effects of combining Lactobacillus buchneri 40788 with various lactic acid bacteria on the fermentation and aerobic stability of corn silage. Anim. Feed Sci. Technol. 159:105-109.

Rooke, J. A., and R. D. Hatfield. 2003. Biochemistry of ensiling. Pages 95-140 in Silage Science and Technology. D. R. Buxton, R. E. Muck, and J. H. Harrison, ed. American Society of Agronomy Inc., Crop Science Society of America Inc., Soil Science Society of America Inc. Publications, Madison, WI.

SAS Institute. 2011. JMP. Version 8.02. SAS Institute Inc., Cary, NC. 
Schmidt, R. J., and L. Kung Jr. 2010. The effects of Lactobacillus buchneri with or without a homolactic bacterium on the fermentation and aerobic stability of corn silages made at different locations. J. Dairy Sci. 93:1616-1624.

Shakeri, J., and H. A. Foster. 2007. Proteolytic activity and antibiotic production by Trichoderma harzianum in relation to pathogenicity to insects. Enzyme Microb. Technol. 40:961-968.

Siala, R., A. Sellami-Kamoun, M. Hajji, I. Abid, N. Gharsallah, and M. Nasri. 2009. Extracellular acid protease from Aspergillus niger I1: purification and characterization. Afr. J. Biotechnol. 8:45824589

Sigma-Aldrich Co. LLC. 1996. Enzymatic assay of pepsin. Accessed Nov. 11, 2011. http://www.sigmaaldrich.com/etc/medialib/docs/ Sigma/Enzyme_Assay/p6887enz.Par.0001.File.tmp/p6887enz.pdf.

Simpson, D. J. 2001. Proteolytic degradation of cereal prolamins-The problem with proline. Plant Sci. 161:825-838.

Snedecor, G. W., and W. G. Cochran. 1980. Statistical Methods. 6th ed. Iowa State Univ. Press, Ames.

Tilley, J. M. A., and R. A. Terry. 1963. A two-stage technique for the in vitro digestion of forage crops. J. Br. Grassl. Soc. 18:104-111.

Van Soest, P. J., J. B. Robertson, and B. A. Lewis. 1991. Methods for dietary fiber, neutral detergent fiber, and nonstarch polysaccharides in relation to animal nutrition. J. Dairy Sci. 74:3583-3597.
Wang, P., D. B. Johnson, K. D. Rausch, S. J. Schmidt, M. E. Tumbleson, and V. Singh. 2009. Effects of protease and urea on a granular starch hydrolyzing process for corn ethanol production. Cereal Chem. 86:319-322.

Wang, Y., W. Xue, A. H. Sims, C. Zhao, A. Wang, G. Tang, J. Qin, and H. Wang. 2008. Isolation of four pepsin-like protease genes from Aspergillus niger and analysis of the effect of on heterologous laccase expression disruptions. Fungal Genet. Biol. 45:17-27.

Weatherburn, M. W. 1967. Phenol-hypochlorite reaction for determination of ammonia. Anal. Chem. 39:971-974.

Wetherall, J. A., D. G. Armstrong, H. J. Finlayson, and J. A. Rooke. 1995. Reduction of proteolysis during ensiling of perennial ryegrass by protease inhibitors. J. Sci. Food Agric. 68:497-505.

Winters, A. L., F. R. Minchin, T. P. T. Michaelson-Yeates, M. R. F. Lee, and P. Morris. 2008. Latent and active polyphenol oxidase (PPO) in red clover (Trifolium pratense) and use of a low PPO mutant to study the role of PPO in proteolysis reduction. J. Agric. Food Chem. 56:2817-2824. 